\title{
FLEXIBLE THIN FILMS FOR SOLAR CELLS BASED ON CADMIUM SULFIDE
}

\author{
R. V. ZAITSEV", M. G. KHRYPUNOV, M. V. KIRICHENKO, I. V. KHRYPUNOVA \\ Materials for Electronics and Solar Cells Department, National Technical University "Kharkiv Polytechnic Institute", Kharkiv, \\ UKRAINE \\ *email: zaitsev.poman@gmail.com
}

\begin{abstract}
For the purpose of creation of the economic, suitable for large-scale application technology of formation of a layer of wide-scale "window", for thin-film photo-electric converters on the basis of sulfide and telluride of cadmium the pilot studies of temperature effect of a deposition of the films of sulfide of cadmium received by method of magnetron dispersion on a direct current on their optical properties and crystalline structure were conducted. By method of a two-channel optical spectroscopy it is established that a deposition of films of sulfide of cadmium at a temperature of $160{ }^{\circ} \mathrm{C}$ allows to form layers with a width of forbidden region of 1,41 eV that approaches value, characteristic of monocrystals, and the density of the photon flux passing through a cadmium sulfide layer in a spectral interval of a photosensitivity of telluride of cadmium at the level of $37,0 \mathrm{~W} \cdot \mathrm{nm} \cdot \mathrm{cm}^{2}$.

Keywords: cadmium sulfide films; a method of magnetron dispersion on a direct current; optical losses; width of the forbidden region; crystalline structure
\end{abstract}

\section{ГНУЧКІ ТОНКІ ПЛІВКИ ДЛЯ СОНЯЧНИХ ЕЛЕМЕНТІВ НА СУЛЬФІДІ КАДМІЮ}

\section{Р. В. ЗАЙЦЕВ, М. Г. ХРИПУНОВ, М. В. КІРІЧЕНКО, І. В. ХРИПУНОВА}

кафедра фізичного матеріалознавства для електроніки та геліоенергетики, Національний технічний університет «Харківський політехнічний інститут» м. Харків, УКРАЇНА

\begin{abstract}
АНОТАЦІЯ 3 метою створення економічної, придатної для иирокомасштабного застосування технологї формування шару широкозонного «вікна» для тонкоплівкових фотоелектричних перетворювачів на основі сульфіду та телуриду кадмію були проведені експериментальні дослідження впливу температури осадження плівок сульфіду кадмію, отриманих методом магнетронного розпилення на постійному струмі, на їх оптичні властивості і кристалічну структуру. Методом двоканальної оптичної спектроскопї̈ встановлено, щуо осадження плівок сульфіду кадмію при температурі $160{ }^{\circ} \mathrm{C}$ дозволяє формувати шари з шириною забороненої зони 1,41 еВ, шуо наближається до значення, характерного для монокристалів, $і$ густиною потоку фотонів, шо проходять через шар сульфіду кадмію в спектральному інтервалі фоточутливості телуриду кадмію, на рівні $37,0 \mathrm{Bm} \cdot \mathrm{нм}^{\circ} \mathrm{cm}^{2}$.

Ключові слова: плівки на сульфіді кадмію; метод магнетронного розпилення на постійному струмі; оптичні втрати; иирина забороненої зони; кристалічна структура.
\end{abstract}

\section{Introduction}

In the modern designs of film photo-electric converters (PhEC) on the basis of telluride of cadmium of a back configuration for reduction of speed of the surface recombination of the nonequilibrium charge carriers generated under the influence of light the effect of widescale "window" is used [1]. This effect consists areas of the fissile oscillation of nonequilibrium charge carriers from the flawed lit surface by use in a design of PhEC of films the wide-scale of the semiconductor materials possessing a high transmittance in the spectral range corresponding to area of a spectral photosensitivity of a basic layer at a distance. Numerous pilot studies (see, for example, [2, 3]) showed that for film PhEC with a basic layer of telluride of cadmium as wide-scale "window", the optimal solution is use of thin films of sulfide of cadmium. Cadmium sulfide for film PhEC is traditionally made by the following methods: thermal vacuum evaporation, a deposition in selfcontained volume, a chemical deposition and high-pitched magnetron dispersion $[4,5]$. CdS films received by these methods have stable vyurttsitny crystalline structure, possess a high transmittance in the spectral range corresponding to the range of a photosensitivity of telluride of cadmium are characterized by good adhesion to a layer of the frontal transparent electrode applied on a glass substrate. In a design of the most efficient film PhEC with a basic layer of telluride of cadmium, received by a chemical deposition, CdS films with thickness no more than 100 nanometers are used [6]. However the method of a chemical deposition is problematic to be adapted to conditions of quantity production as it is characterized by low speeds of growth of a film of sulfide of cadmium. At the same time it is necessary to solve issues of regeneration of a fluid chemical wastage. More technological in the conditions of quantity production is the method of thermal vacuum evaporation. However, the conducted researches (see, for example, [7]) showed that thickness of the films of sulfide of cadmium received by this method for use in PhEC on the basis of telluride of cadmium has to be not less than 0,3 microns. Otherwise, owing to through porosity of the films of sulfide of cadmium received by this method which arises owing to 
geometrical effect of a shadowing of a surface by the most quickly growing grains a shunting of the separating barrier of instrument structure because of an electrical link of a basic layer of telluride of cadmium to the frontal electrode takes place. The cadmium sulfide films received by method of high-pitched magnetron dispersion are deprived of this shortcoming. However, the large-scale technical application of this method is limited by the high cost of the high-pitched power supply. At the same time, economic, well mastered by domestic electronic industry, the method of not jet magnetron dispersion on a direct current for receiving films of sulfide of cadmium practically is not used.

Thus, the pilot studies of the influence of parameters of magnetron not jet dispersion on a direct current on crystalline structure and optical properties of films of sulfide of cadmium are urgent for creation of the industrial vacuum technologies of receiving of the widescale of "windows" for film photo-electric converters with a basic layer of telluride of cadmium of a back configuration.

\section{Technique of carrying out experiment}

For receiving films of sulfide of cadmium by the method of not jet magnetron dispersion on a direct current [8] developed and made the magnetron adapted to a design of the UVN reference production vacuum installation - 71 P3 (figure 1). Installation of a magnetron was carried out through a peep-hole of vacuum installation (the figure 1, c).

The design of a magnetron allowed to use target material efficiently. It was caused by the fact that with a diameter of magnetron of $100 \mathrm{~mm}$, diameter of a zone of an erosion made $65 \mathrm{~mm}$, and its width $10-12 \mathrm{~mm}$. Such sizes of a zone of erosion allowed to put films of $70 \mathrm{~mm}$ by 70 $\mathrm{mm}$ in size with uniformity of thickness at the level of 5\%. Therefore, the applied to receiving films, magnetron system can be used in the conditions of the industrial production. Express adaptation allowed moving a substrate together with heating section and the heat-insulating screen in the horizontal plane to such situation at which during preliminary heating pollution of a target was excluded. The target 1 representing the disk with a diameter of $10 \mathrm{~cm}$ pressed from cadmium sulfide powder by purity of $99,99 \%$ was a source of the sprayed material. The target settled down on a surface of the water-cooled magnetron. In the bottom of the anode of a magnetron there was an input for a tube on which supply of gas mixture of argon and oxygen in spraying system was carried out. The developed design of the radiation heater of a substrate as which glass plates $\mathrm{K}$ 8 with thickness of $2 \mathrm{~mm}$ thick were used allowed to warm evenly on the area a substrate up to the established temperature in the range of $100-220{ }^{\circ} \mathrm{C}$ and to maintain temperature with an accuracy of \pm of $2{ }^{\circ} \mathrm{C}$ by means of an automatic regulating system.

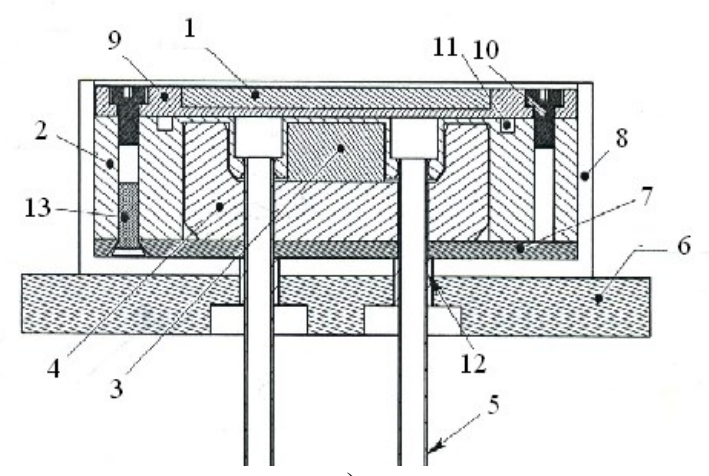

a)

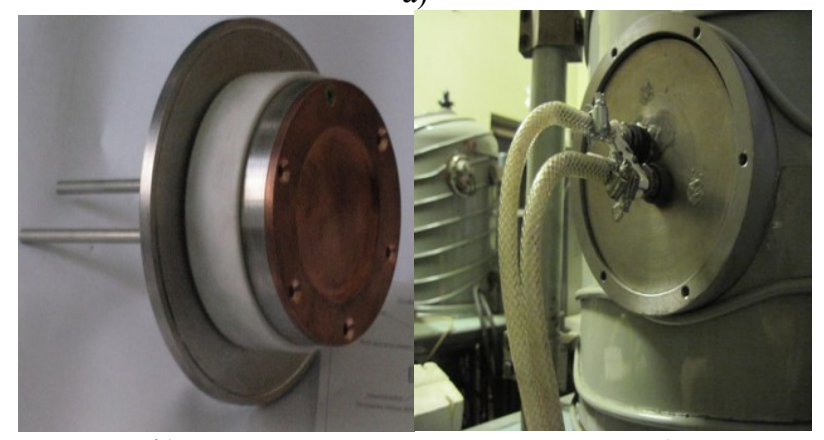

b)

c)

1 - target; 2 - housing; 3 - permanent magnet of NdFeB; 4 - magnetic circuit; 5 - cooling tube; 6 -adjusting flange; 7 - cover; 8 -insulator of a housing; 9 -target basis; 10 screw of fastening of a target (M4x7); 11 -vacuum seal, 12 - the insulator of a tube of cooling, 13 - the screw of fixing of a cover

\section{Fig. 1 - The key diagram (a), photos of a magnetron (b) and installation of magnetron dispersion (c)}

The design of a magnetron allowed using target material efficiently. It was caused by the fact that with a diameter of magnetron of $100 \mathrm{~mm}$, diameter of a zone of an erosion made $65 \mathrm{~mm}$, and its width $10-12 \mathrm{~mm}$. Such sizes of a zone of erosion allowed to put films of $70 \mathrm{~mm}$ by 70 $\mathrm{mm}$ in size with uniformity of thickness at the level of $5 \%$. Therefore, the applied to receiving films, magnetron system can be used in the conditions of the industrial production. Express adaptation allowed moving a substrate together with heating section and the heat-insulating screen in the horizontal plane to such situation at which during preliminary heating pollution of a target was excluded. The target 1 representing the disk with a diameter of $10 \mathrm{~cm}$ pressed from cadmium sulfide powder by purity of $99,99 \%$ was a source of the sprayed material. The target settled down on a surface of the water-cooled magnetron. In the bottom of the anode of a magnetron there was an input for a tube on which supply of gas mixture of argon and oxygen in spraying system was carried out. The developed design of the radiation heater of a substrate as which glass plates $\mathrm{K}$ 8 with thickness of $2 \mathrm{~mm}$ thick were used allowed to warm evenly on the area a substrate up to the established temperature in the range of $100-220{ }^{\circ} \mathrm{C}$ and to maintain 
temperature with an accuracy of \pm of $2{ }^{\circ} \mathrm{C}$ by means of an automatic regulating system.

The common pressure of the sprayed gas necessary for operational stability of a magnetron, made 2 Pas. Therefore, between the building bag and the pump the limitative diaphragm necessary for stable work of a vacuum vapor-steam pump at such low pressure was established. The distance from a substrate to a target which made $35 \mathrm{~mm}$, was defined as minimum at which inhomogeneity of the received film on thickness taking into account a geometrical factor was not exceeded by $5 \%$.

Crystalline structure and phase structure of films were investigated on a X-ray diffractometer the DRON$4 \mathrm{M}$ in monochromatic $\mathrm{Co}-\mathrm{K} \alpha$ radiation. Identification of phases in models was carried out on the basis of comparison of set of the interplanar distances calculated by Woolf - Bragg's formula [9], with the available sets of interplanar distances for tin oxides from the help ASTM cards. Roughing-out of the diffraction peaks was carried out by means of the developed computer program. Such computing machining allowed defining the position of the

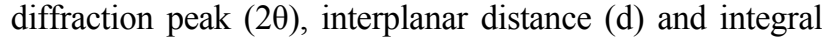
intensity (I).

Spectral dependences of the coefficients of transmittances and reflection of films of sulfide of cadmium investigated by method of a two-channel optical spectroscopy by means of a spectrophotometer SPh- 2000, equipped with the SPhO prefix - 2000 for measurement of reflecting and diffuse reflections. Optical width of the forbidden region of Eg layers of $\mathrm{CdS}$ defined similarly described in [9], by means of extrapolation on an axis of energies of the line section, dependence $[-\ln (\mathrm{T}) \cdot \mathrm{h} v]^{2}$ from hv.

\section{Results and theirdiscussion}

\section{Research of optical properties of films of sulfide of cadmium}

Films of sulfide of cadmium were received by method of magnetron dispersion on a direct current with a pressure of working gas of $0,9-1 \mathrm{~Pa}, 550-600 \mathrm{~V}$ tension category and current densities $0,44-0,53 \mathrm{~mA} / \mathrm{cm}^{2}$. At the same time precipitation temperature varied from $100{ }^{\circ} \mathrm{C}$ to $230{ }^{\circ} \mathrm{C}$. Such ranges of parameters of the technological modes can be considered suitable for procreation in the production conditions. Time of a deposition of films made 5 minutes.

The research of optical properties of films of sulfide of cadmium was conducted by means of measurements of spectral dependences of transmittances and reflection of films of $\mathrm{CdS}$ in the spectral range of 400 - 1100 nanometers (figure 2). The analysis of transmission spectrums shows that for all models, except the model received at precipitation temperature of $100{ }^{\circ} \mathrm{C}$ the strong absorption in the range of lengths of waves of 400 - 500 nanometers and a sharp edge of an absorption band in the range of $500-550$ nanometers is observed. At the same time in red and infrared spectral ranges a high transparence at the level of $80 \%$ is observed.
Analytical processing of transmission spectrums and reflection allowed to determine optical parameters of the studied films received at various precipitation temperatures.

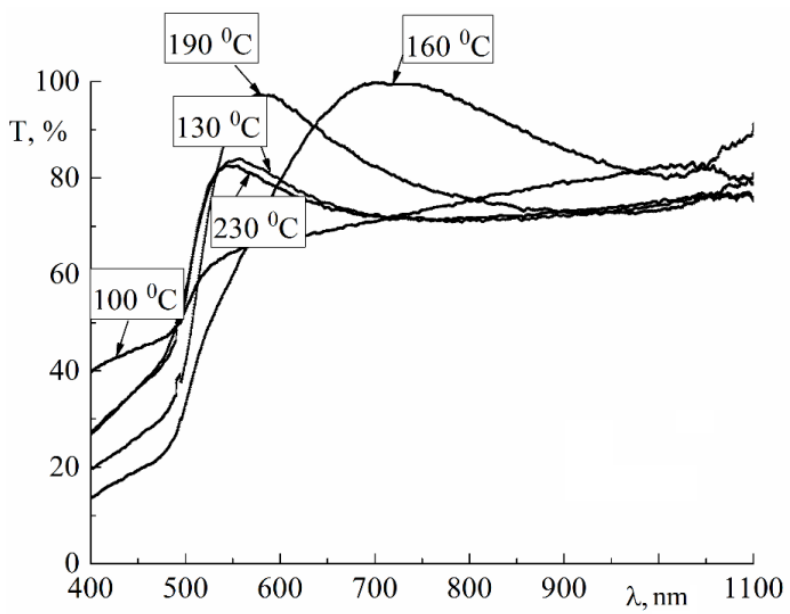

Fig. 2 - Spectral dependences of the coefficients of transmittances of the films of sulfide of cadmium received at various precipitation temperatures

In the figure 3 results of definition of width of the forbidden region $\left(E_{g}, e V\right)$ and values of theoretical power of a luminous flux (W, Wt.nanometer $\cdot \mathrm{cm}^{2}$ ) which can pass through the studied cadmium sulfide films in the conditions of illumination of AM 1,5, in a spectral interval of a photosensitivity of PhEC on the basis of sulfide and telluride of cadmium which, according to literary data [8], makes 550-900 nanometers are given. These two parameters determine the size of optical losses in a cadmium sulfide layer at its use as wide-scale "window" in film photo-electric converters with a basic layer of telluride of cadmium of a back configuration. Optical researches showed that with growth of precipitation temperature to $160^{\circ} \mathrm{C}$ there is an increase, passed from through a film of sulfide of cadmium, power of a luminous flux $32,7 \mathrm{~W} \cdot \mathrm{nm} \cdot \mathrm{cm}^{2}$ to $37 \mathrm{~W} \cdot \mathrm{nm} \cdot \mathrm{cm}^{2}$. Further growth of precipitation temperature to $230^{\circ} \mathrm{C}$ leads to decrease in last power of a luminous flux to 33,5 $\mathrm{Wt} \cdot$ nanometer $\cdot \mathrm{cm}^{2}$. The analysis of the figure 3 demonstrates that with growth of precipitation temperature from $100^{\circ} \mathrm{C}$ to $160^{\circ} \mathrm{C}$ there is an increase in width of the forbidden region from $2,38 \mathrm{eV}$ to $2,41 \mathrm{eV}$.

Further growth of precipitation temperature from $160^{\circ} \mathrm{C}$ to $230^{\circ} \mathrm{C}$ leads to decrease in width of the forbidden region from $2,41 \mathrm{eV}$ to $2,39 \mathrm{eV}$. According to literary data [4] for monocrystal films of sulfide of cadmium width of the forbidden region makes 2,42-2,45 $\mathrm{eV}$. Smaller values of width of the forbidden region for polycrystalline films of sulfide of cadmium, in comparison with monocrystals, are caused by the fact that borders of grains absorb light as metal layers that leads to decrease in size of the forbidden region determined by optical techniques. Except a developed grain bordered surface decrease in optical width of the forbidden region 
can be caused by impoverishment of films of sulfide of cadmium by easily volatile component - sulfur.

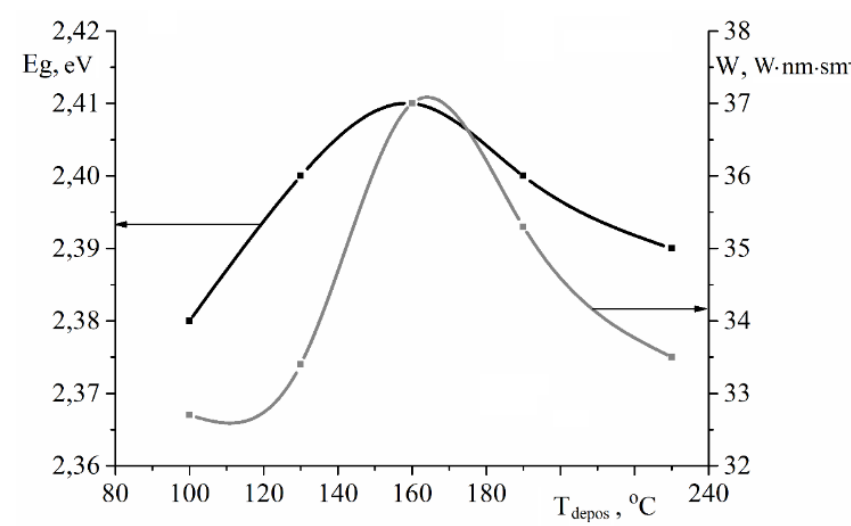

Fig. 3 - Optical parameters of films of CdS received by the method of magnetron dispersion

Thus, for use in a design of high performance $\mathrm{PhEC}$ on the basis of sulfide and telluride of cadmium it is necessary to use the films received at precipitation temperature of $160{ }^{\circ} \mathrm{C}$ as at the same time the maximal stream density fluency of the photons coming to a basic layer of telluride of cadmium that allows to increase the coefficient of efficiency due to growth of a current density of a short-circuit.

2. Research of crystalline structure and element structure of films of sulfide of cadmium

For identification of the physical mechanisms defining dependence of width of the forbidden region of the films of sulfide of cadmium received by magnetron dispersion on a direct current research of crystalline structure of films were conducted by method of a x-ray diffractometry (fig. 4). On the experimental roentgen diffracto-grammas only one peak on angle $2 \theta=30,62^{\circ}$ which corresponds to reflection (111) cubic modification or to reflection (002) of the hexagonal phase CdS which are theoretically characterized by the maximal intensity is observed. Because of the small thickness of a model other diffraction peaks were not identified that does not allow to uniquely determinate phase structure of the received CdS models by a roentgen diffracto metrical method. Nevertheless, in view of the fact that stable modification of $\mathrm{CdS}$ is hexagonal, further processing investigated roentgen diffrakco-gramm was carried out for the hexagonal phase CdS. Results of analytical processing of structural researches are presented in table 1 .

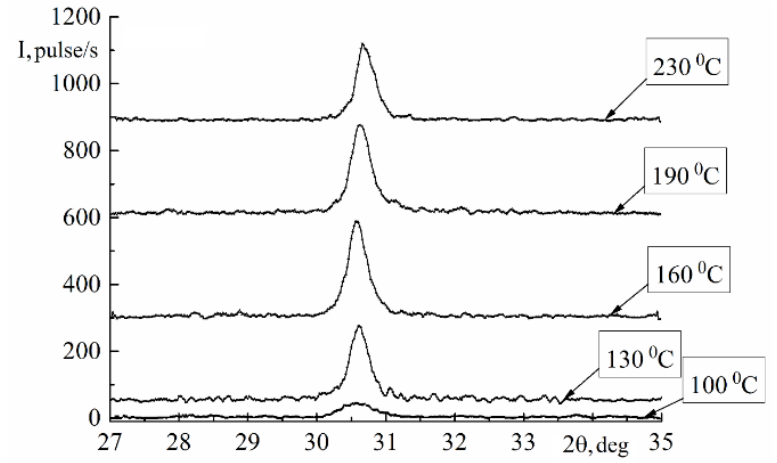

Fig. 4 -Roentgen diffracto-gramma of the films of sulfide of cadmium received by method of magnetron dispersion on a direct current at various precipitation temperatures

Table 1 - Results of analytical processing of structural researches of films of CdS received by method of magnetron dispersion on a direct current

\begin{tabular}{|c|c|c|c|c|c|}
\hline No & $\begin{array}{c}\text { Precipit } \\
\text { ation } \\
\text { tempera } \\
\text { ture, }{ }^{0} \mathrm{C}\end{array}$ & $\begin{array}{c}\text { Positio } \\
\text { n of } \\
\text { peak, } \\
\text { degree }\end{array}$ & $\begin{array}{c}\text { Inter- } \\
\text { planar } \\
\text { distance } \\
(\mathrm{d} 002), \\
\AA\end{array}$ & $\begin{array}{c}\text { Half-width } \\
\text { of the } \\
\text { diffraction } \\
\text { peak }(\Delta \theta), \\
\text { degree }\end{array}$ & L, nm \\
\hline 1 & 100 & 30,58 & 3,391 & 0,38 & 25,2 \\
\hline 2 & 130 & 30,62 & 3,388 & 0,33 & 29,0 \\
\hline 3 & 160 & 30,59 & 3,391 & 0,33 & 29,0 \\
\hline 6 & 190 & 30,64 & 3,385 & 0,34 & 28,1 \\
\hline 5 & 230 & 30,70 & 3,379 & 0,30 & 31,9 \\
\hline
\end{tabular}

With growth of precipitation temperature from $100^{\circ} \mathrm{C}$ to $230^{\circ} \mathrm{C}$ decrease in interplanar distance (002) from $\mathrm{d}_{002}=3,391 \AA$ to $\mathrm{d}_{002}=3,379 \AA$ is observed, that corresponds to decrease in parameter from a hexagonal lattice from $\mathrm{c}=6,782 \AA$ to $\mathrm{c}=6,758 \AA$. The received values of parameter $\mathrm{c}$ is more than table value, what is characteristic for monocrystals $(\mathrm{c}=6,7198 \AA$ ). It demonstrates existence of the squeezing macrovoltage which size decreases with increase of temperature up to $230{ }^{\circ} \mathrm{C}$. With increase of precipitation temperature from $100{ }^{\circ} \mathrm{C}$ to $230^{\circ} \mathrm{C}$ decrease of a physical broadening of the diffraction peak from $\Delta \theta=0,38^{\circ}$ to $\Delta \theta=0,30^{\circ}$ is observed. The assessment on the specified width of the diffraction peaks shows that with increase of precipitation temperature growth of areas of a coherent scattering from 25,2 nanometers to 31,9 nanometers is observed. Thus, with increase of precipitation temperature from $100{ }^{\circ} \mathrm{C}$ to $230{ }^{\circ} \mathrm{C}$ natural increase in quality of crystalline structure of films of sulfide of cadmium is observed: decrease in level of macrovoltages and increase in the sizes of areas of a coherent scattering is observed that reduces light absorption on a developed grainbordered surface. Decrease in level of microdeformation and growthof the sizes of areas of a coherent scattering cause growthof optical width of the forbidden region. 
Researches of crystalline structure were added with researches of elemental structure of the received films which were conducted on a spectrometer Elvatech of the Elvate company. Time of set of impulses made 240-241 second. Researches showed (fig. 5) that with increase of precipitation temperature from $100{ }^{\circ} \mathrm{C}$ to 230 ${ }^{\circ} \mathrm{C}$ the attitude of atomic concentration of sulfur $\left(\mathrm{C}_{\mathrm{S}}\right)$ towards atomic concentration of cadmium $\left(\mathrm{C}_{\mathrm{Cd}}\right)$ decreases from $\mathrm{C}_{\mathrm{S}} / \mathrm{C}_{\mathrm{Cd}}=1,06$ to $\mathrm{C}_{\mathrm{S}} / \mathrm{C}_{\mathrm{Cd}}=0,95$ that is bound to impoverishment of the growing film an easily volatile component which sulfur is.

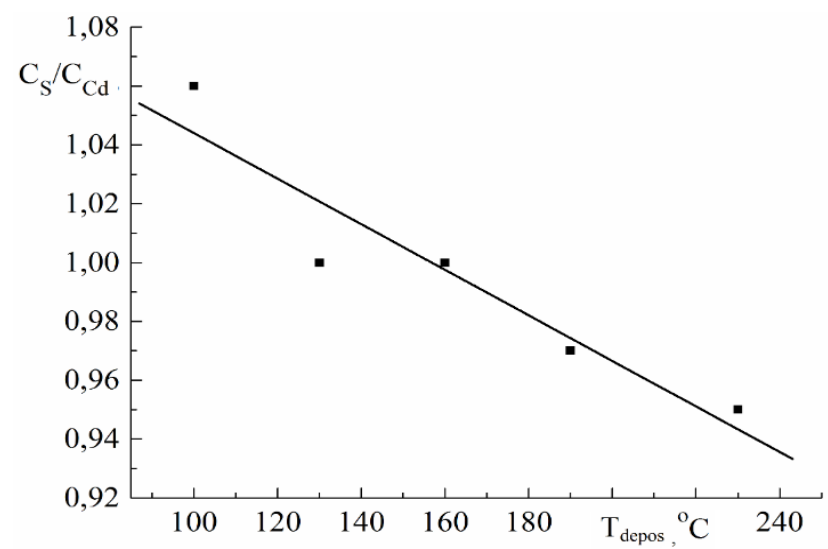

Fig. 5 - The relation of atomic concentration of sulfur and cadmium of the films of sulfide of cadmium received by method of magnetron dispersion on a direct current at various precipitation temperatures

Thus, with increasing of precipitation temperature decrease in degree of stoichiometry of films that is caused by increasing of a vacancies concentration, causing growth of light absorption and decrease of efficient optical width of the forbidden region, as a result of emergence in the forbidden region of the energy levels capable to share in the transition of charge carriers activated by light is observed.

\section{Conclusions}

For use in a design of film photo-electric converters of a back configuration with a basic layer of telluride of cadmium optimum precipitation temperature of films of sulfide of cadmium by method of not jet magnetron dispersion on a direct current makes $160{ }^{\circ} \mathrm{C}$ that is caused by achievement of the greatest width of the forbidden region $-1,41 \mathrm{eV}$ and the maximal flux density of the photons arriving through a cadmium sulfide layer in the spectral range of a photosensitivity of telluride of cadmium. The extremum on dependence of optical properties of the studied cadmium sulfide films from precipitation temperature is caused by existence of two competing physical mechanisms. Body height of precipitation temperature to $160{ }^{\circ} \mathrm{C}$ leads to decrease in optical losses in cadmium sulfide films, as a result of increase in the sizes of areas of a coherent scattering and decrease of level of macrodeformations. At further increase of precipitation temperature up to $230{ }^{\circ} \mathrm{C}$ the defining factor leading to growth of optical losses in cadmium sulfide films becomes their impoverishment by an easily volatile component - sulfur.

\section{Bibliography}

1. Han, J. Optimized chemical bath deposited cds layers for the improvement of cdte solar cells / J. Han, C. Spanheimer, G. Haindl, Fu Ganhua, V. Krishnakumar, J. Schaffner, C. Fan, K. Zhao, A. Klein, W. Jaegermann // Solar Energy Materials and Solar Cells. - 2011. - 95(3). 816 - 820. - doi: 10.1016/j.solmat.2010.10.027.

2. Liu, $\mathbf{P}$. Cadmium sulfide nanowires for the window semiconductor layer in thin film CdS-CdTe solar cells / P. Liu, V. P. Singh, C. A. Jarro, S. Rajaputra // Nanotechnology. - 2011. - 14(22). - 1-9. - doi: 10.1088/0957-4484/22/14/145304.

3. Rubio, S. Influence of $\mathrm{CdS}$ deposition technique for $\mathrm{CdS} / \mathrm{CdTe}$ solar cells / S. Rubio, J. L. Plaza, E. Dieguez // Journal of Crystal Growth. - 2014. - 401. 550-553. - doi: 10.1016/j.jcrysgro.2014.03.032.

4. Jaber, A. Y. Influence of substrate temperature on thermally evaporated $\mathrm{CdS}$ thin film properties / A. Y. Jaber, M. S. Aida, M. Benghanem, A. A. Abdelaziz // Journal of Alloys and Compounds. - 2012. - 529. - 63-68. doi: 10.1016/j.jallcom.2012.03.093.

5. Lisco, F. The structural properties of CdS deposited by chemical bath deposition and pulsed direct current magnetron sputtering / F. Lisco, P. M. Kaminski, A. Abbas, K. Bass, J. W. Bowers, G. Claudio, M. Losundro, J. M. Walls // Thin Solid Films. - 2015. - 582. 323- 327. - doi: 10.1016/j.tsf.2014.11.062.

6. Krishnakumar, V. Close spaced sublimation deposition of CdTe layers with process gas oxygen for thin film solar cells / V. Krishnakumar, B. Späth, C. Drost, C. Kraft, B. Siepchen, A. Delahoy, X. Tan, K. Chin, S. Peng, D. Hirsch, O. Zywitzki, T. Modes, H. Morgner // Thin Solid Films. - 2017. - 633. - 112-117. - doi: 10.1016/j.tsf.2016.10.009.

7. Khrypunov, G. Recent developments in evaporated CdTe solar cells / G. Khrypunov, A. Romeo, F. Kurtzesau, D. L. Batzner, H. Zogg, A. N. Tiwari // Solar Energy Materials \& Solar Cells. - 2006. - 90(6). - 664-677. - doi: 10.1016/j.solmat.2005.04.003.

8. Kuzmichyov, A. I. Magnetron spraying systems. Introduction to physics and technology of magnetron dispersion / A. I. Kuzmichyov. Kiev: "Avers". - 2008. Book 1. -244.

9. Klochko, N. P. Electrodeposited zinc oxide arrays with the moth-eye effect / N. P. Klochko, G. S. Khrypunov, Y. O. Myagchenko, E. E. Melnychuk, V. R. Kopach, K. S. Klepikova, V. M. Lyubov, A. V. Kopach // Semiconductors. - 2014. - 48. - 531-537. - doi: $10.1134 / \mathrm{S} 1063782614040162$.

\section{Bibliography (transliterated)}

1. Han, J., Spanheimer, C., Haindl, G., Ganhua, Fu, Krishnakumar, V., Schaffner, J., Fan, C., Zhao, K., Klein, A., Jaegermann, W. Optimized chemical bath deposited cds layers for the improvement of cdte solar cells. Solar Energy Materials and Solar Cells, 2011, 95(3), 816 820, doi: 10.1016/j.solmat.2010.10.027. 
2. Liu, P., Singh, V. P., Jarro, C. A., Rajaputra, S. Cadmium sulfide nanowires for the window semiconductor layer in thin film CdS-CdTe solar cells. Nanotechnology, 2011, 14(22), 1-9, doi: 10.1088/0957-4484/22/14/145304.

3. Rubio, S., Plaza, J. L., Dieguez, E. Influence of CdS deposition technique for $\mathrm{CdS} / \mathrm{CdTe}$ solar cells. Journal of Crystal Growth, 2014, 401, 550-553, doi 10.1016/j.jcrysgro.2014.03.032.

4. Jaber, A. Y., Aida, M. S., Benghanem, M., Abdelaziz, A. A. Influence of substrate temperature on thermally evaporated CdS thin film properties. Journal of Alloys and Compounds, 2012, 529, 63-68, doi: 10.1016/j.jallcom.2012.03.093.

5. Lisco, F., Kaminski, P. M., Abbas, A., Bass, K. Bowers, J. W., Claudio, G., Losundro, M., Walls, J. M. The structural properties of CdS deposited by chemical bath deposition and pulsed direct current magnetron sputtering. Thin Solid Films, 2015, 582, 323- 327, doi 10.1016/j.tsf.2014.11.062.
6. Krishnakumar, V., Späth, B., Drost, C., Kraft, C., Siepchen, B., Delahoy, A., Tan, X., Chin, K., Peng, S., Hirsch, D., Zywitzki, O., Modes, T., Morgner, H. Close spaced sublimation deposition of CdTe layers with process gas oxygen for thin film solar cells. Thin Solid Films, 2017, 633, 112-117, doi: 10.1016/j.tsf.2016.10.009.

7. Khrypunov, G., Romeo, A., Kurtzesau, F., Batzner, D. L., Zogg, H., Tiwari, A. N. Recent developments in evaporated CdTe solar cells. Solar Energy Materials \& Solar Cells, 2006, 90(6), 664-677, doi: 10.1016/j.solmat.2005.04.003

8. Kuzmichyov, A. I. Magnetron spraying systems. Introduction to physics and technology of magnetron dispersion. Kiev: "Avers", 2008, Book 1, 244.

9. Klochko, N. P., Khrypunov, G. S., Myagchenko, Y. O., Melnychuk, E. E., Kopach, V. R., Klepikova, K. S., Lyubov, V. M., Kopach, A. V. Electrodeposited zinc oxide arrays with the moth-eye effect. Semiconductors, 2014, 48, 531-537, doi: 10.1134/S1063782614040162.

\section{About authors (відомості про авторів)}

Zaitsev Roman - Ph. D., Head of Department, Materials for Electronica and Solar Cells Department, National Technical University "Kharkiv Polytechnic Institute”, Kharkiv, Ukraine; e-mail: zaitsev.poman@gmail.com.

Зайцев Роман - кандидат технічних наук, доцент, Національний технічний університет «Харківський політехнічний інститут», завідувач кафедри фізичного матеріалознавства для електроніки та геліоенергетики, м. Харків, Україна; е-таil: zaitsev.poman@gmail.com.

Khrypunov Maksim - PhD student, Materials for Electronica and Solar Cells Department, National Technical University "Kharkiv Polytechnic Institute”, Kharkiv, Ukraine; e-mail: lauman@ukr.net.

Хрипунов Максим - аспірант, Національний технічний університет «Харківський політехнічний інститут», кафедра фізичного матеріалознавства для електроніки та геліоенергетики, м. Харків, Україна; e-mail: lauman@ukr.net.

Kirichenko Michailo - Ph. D., Senior Researcher, Materials for Electronica and Solar Cells Department, National Technical University "Kharkiv Polytechnic Institute", Kharkiv, Ukraine; e-mail: : kirichenko.mv@gmail.com.

Кіріченко Михайло - кандидат технічних наук, старший науковий співробітник, Національний технічний університет «Харківський політехнічний інститут», кафедра фізичного матеріалознавства для електроніки та геліоенергетики, м. Харків, Україна; e-mail: : kirichenko.mv@gmail.com.

Khrypunova Irina - PhD student, Materials for Electronica and Solar Cells Department, National Technical University "Kharkiv Polytechnic Institute", Kharkiv, Ukraine; e-mail: lauman@ukr.net.

Хрипунова Ірина - аспірантка, Національний технічний університет «Харківський політехнічний інститут», кафедра фізичного матеріалознавства для електроніки та геліоенергетики, м. Харків, Україна; e-mail: lauman@ukr.net.

Please cite this article as:

Zaitsev, R., Khrypunov, M., Kirichenko, M., Khrypunova, I. Flexible thin films for solar cell based on cadmium sulfide. Bulletin of NTU "KhPI". Series: New solutions in modern technologies. - Kharkiv: NTU "KhPI", 2018,26 (1302), 1, 42-47, doi:10.20998/2413-4295.2018.26.06.

Будь ласка, посилайтесь на ию статтю наступним чином:

Зайцев, Р. В. Гнучкі тонкі плівки для сонячних елементів на сульфіді кадмію / Р. В. Зайцев, М. Г. Хрипунов, М. В. Кіріченко, І. В. Хрипунова // Вісник НТУ «ХПІ», Серія: Нові рішення в сучасних технологіях. - Харків: НТУ «ХПІ». 2018. - № 26 (1302). - T. 1. - C. 42-47. - doi:10.20998/2413-4295.2018.26.06

Пожалуйста, ссылайтесь на эту статью следующим образом:

Зайцев, Р. В. Гибкие тонкие пленки для солнечных элементов на сульфиде кадмия / Р. В. Зайцев, М. Г. Хрипунов, М. В. Кириченко, И. В. Хрипунова // Вестник НТУ «ХПИ», Серия: Новые решения в современных технологиях. - Харьков: НТУ «ХПИ». - 2018. - № 26 (1302). - Т. 1. - С. 42-47. - doi:10.20998/2413-4295.2018.26.06.

АННОТАЦИЯ С иелью создания экономической, пригодной для иирокомасштабного применения технологии формирования слоя широкозонного «окна» для тонкопленочных фотоэлектрических преобразователей на основе сульфида и теллурида кадмия были проведены экспериментальные исследования влияния температуры осаждения пленок сульфида кадмия, полученных методом магнетронного распыления на постоянном токе, на их оптические свойства $и$ кристаллическую структуру. Методом двухканальной оптической спектроскопии установлено, что осаждение пленок сульфида кадмия при температуре $160^{\circ} \mathrm{C}$ позволяет формировать слои с шириной запрещенной зонь 1,41 эB, что приближается к значению, характерного для монокристаллов, и плотностью потока фотонов, проходящих через слой сульфида кадмия в спектральном интервале фоточувствительности теллурида кадмия на уровне $37,0 \mathrm{Bm} \cdot \mathrm{Hм}^{\cdot} \mathrm{cm}^{2}$.

Ключевые слова: пленки на сульфиде кадмия; метод магнетронного распыления на постоянном токе; оптические потери; ширина запрещенной зоны; кристаллическая структура. 